\title{
PENGARUH BUDAYA KERJA, KOMITMEN, MOTIVASI KERJA GURU TERHADAP IKLIM ORGANISASI SD
}

\author{
Azzi Machwati, Udik Budi Wibowo \\ SDN Ketanggungan 04, Universitas Negeri Yogyakarta \\ azzimachwati69@ymail.com, yube2u@yahoo.com
}

\begin{abstract}
Abstrak
Penelitian ini bertujuan untuk mengungkap pengaruh budaya kerja guru, komitmen guru, dan motivasi kerja guru terhadap iklim organisasi sekolah dasar di Kecamatan Ketanggungan, Kabupaten Brebes. Penelitian ini menggunakan pendekatan kuantitatif dengan jenis penelitian survei. Populasi penelitian ini adalah 55 Sekolah Dasar (SD) di Ketanggungan, dan dengan menggunakan tingkat kesalahan 5\% diperoleh sampel 48 SD yang dipilih dengan menggunakan teknik simple random sampling. Selanjutnya penentuan responden dilakukan dengan teknik stratified random sampling diperoleh 144 guru. Pengumpulan data menggunakan kuesioner dengan validitas item yang mendapat pertimbangan ahli dan uji empirik, selanjutnya reliabilitas instrumen dengan teknik Alpha_Cronbach. Uji persyaratan analisis terdiri atas uji normalitas, homogenitas, dan linearitas, dan uji hipotesis dengan teknik regresi sederhana dan regresi ganda. Hasil analisis deskriptif menunjukkan bahwa iklim organisasi sekolah di sekolah dasar Kecamatan Ketanggungan, Kabupaten Brebes adalah: (1) 6,25\% sekolah memiliki iklim organisasi sangat baik; (2) 18,75\% sekolah memiliki iklim organisasi yang baik; (3) 33,33\% kategori baik; (4) $37,50 \%$ kategori kurang baik; dan (5) 4,17\% sekolah memiliki kategori tidak baik. Hasil pengujian hipotesis menunjukkan bahwa terdapat pengaruh positif dan signifikan budaya kerja guru, komitmen guru, dan motivasi kerja guru terhadap iklim organisasi sekolah (Adjusted $R^{2}=0,418$ ).
\end{abstract}

Kata kunci: budaya kerja, komitmen, motivasi kerja, iklim organisasi

\section{THE EFFECT OF THE TEACHERS' WORK CULTURE, COMMITMENT, AND MOTIVATION ON THE ATMOSPHERE OF ORGANIZATION OF PRIMARY SCHOOLS}

\author{
Azzi Machwati, Udik Budi Wibowo \\ SDN Ketanggungan 04, Universitas Negeri Yogyakarta \\ azzimachwati69@ymail.com, yube2u@yahoo.com
}

\begin{abstract}
This research aims to determine the effect of the teachers' work culture, commitment, and motivation on the atmosphere of organization of primary school in Ketanggungan, Brebes Regency. This survey research used the quantitative approach. The research population consisted of 55 primary schools (SD) in Ketanggungan, using the simple random sampling technique obtained 48 primary schools which has wrong level up to 5\%. In addition, stratified random sampling technique gained the respondent from 144 of teachers. A questionnaire is used to collect the data which has an item validity that it gains the expert's review and the empirical test. Furthermore, an Alpha Chonbach technique gains the reliability of instrument. The pre testing analysis requirements consisted of tests of normality, homogenity, and linearity. The hypothesis testing analyzed by using the simple regression and multiple regression. The result of descriptive analysis shows that the atmosphere of the organization of primary schools in Ketanggungan, Brebes Regency (1) $6.25 \%$ of the organization schools' atmosphere is excellent; (2) $18.75 \%$ of the organization schools' atmosphere is well; (3) $33.33 \%$ of the schools organization atmosphere is in a good category; (4) 37.50\% of schools are net in a good category; and (5) $4.17 \%$ of schools are not in a good category. The result of the hypothesis testing shows that there are positive and significant effects of the teacher work culture, commitment, and motivation on the teachers schools' organization atmosphere (Adjusted $R^{2}=0,418$ ).
\end{abstract}

Keywords: working culture, commitment, working motivation, organization climate 



\section{Pendahuluan}

Perkembangan dan kemajuan ilmu pengetahuan dan teknologi saat ini telah mengantarkan manusia ke era globalisasi. Era globalisasi dipandang sebagai era yang mengedepankan ilmu pengetahuan dan teknologi sebagai landasan utama dalam semua aspek kehidupan, termasuk dalam dunia pendidikan. Proses pendidikan sebagai rangkaian kegiatan pembentukan karakter dan budaya manusia memiliki tantangan semakin rumit dan komplek.

Pemerintah selaku penyelenggara pendidikan nasional merupakan pihak yang paling bertanggung jawab atas proses pendidikan secara keseluruhan, karena pemerintah memiliki peranan yang sangat strategis dalam menentukan keberhasilan proses pendidikan di semua lembaga pendidikan atau sekolah. Untuk mendukung proses pendidikan tersebut, ada banyak aspek yang harus diperhatikan oleh pemerintah, salah satunya adalah aspek iklim organisasi sekolah.

Iklim organisasi sekolah itu sendiri merupakan karakteristik dari keseluruhan lingkungan pada suatu bangunan sekolah. Artinya, suatu keadaan atau ciri-ciri atau sifat yang menggambarkan lingkungan psikologis organisasi yang dirasakan orang yang berada dalam lingkungan sekolah tersebut, seperti suasana kerja, interaksi antara guru dan kepala sekolah, guru dengan guru, antara sekolah dengan masyarakat sekitar, serta sistem sosial dan budaya.

Upaya mewujudkan iklim organisasi yang sehat dan menyenangkan diperlukan usaha perbaikan sejalan dengan budaya yang dikembangkan dalam dunia pendidikan, sehingga inisiatif, kreativitas, dan sikap proaktif guru tumbuh dengan penuh tanggung jawab bagi sekolah. Untuk ini sekolah harus berupaya mengembangkan unsur-unsur yang dapat mewujudkan iklim organisasi yang sehat dan menyenangkan.

Berikut ini hasil penelitian yang dilakukan oleh Pusat Penelitian Kebijakan Badan Penelitian Dan Pengembangan Kementerian Pendidikan Nasional bekerja sama dengan Word Bank, tentang angka kemangkiran, yaitu menemukan tingkat kemangkiran guru SD pada hari sidak $(\mathrm{H})$ ternyata cukup tinggi, yakni mean $8,35 \%$, dan median $7,9 \%$. Artinya perlu penanganan yang serius karena pengaruhnya langsung terhadap proses pembelajaran.

Tingkat kemangkiran guru ini berkaitan dengan aturan tata tertib yang merupakan pelanggaran kedisiplinan, sehingga ini bisa disebut sebagai bagian budaya kerja yang bermasalah. Hal ini mengindikasikan bahwa iklim organisasi sekolah terganggu karena adanya kemangkiran yang dilakukan oleh guru.

Untuk mendapatkan iklim organisasi yang kondusif, selain dipengaruhi oleh budaya kerja guru, juga dipengaruhi oleh komitmen guru. Pada aspek komitmen ini, di lapangan masih ditemui adanya guru yang ingin pindah ke sekolah lain, atau sebaliknya, tidak mau bila ditempatkan di sekolah tertentu. Loyalitas terhadap pimpinan dan institusi masih kurang. Selain itu ada guru yang tidak bangga dengan keberhasilan, sehingga tidak ada komitmen untuk meraih sukses. Situasi seperti ini merupakan gambaran rendahnya komitmen guru untuk memajukan sekolah.

Dalam usaha mencapai tujuan sekolah selain dipengaruhi oleh budaya kerja guru, komitmen guru, juga dipengaruhi oleh motivasi kerja guru. Keadaan di lapangan menunjukkan bahwa beberapa guru masih memiliki motivasi kerja yang rendah. Hal ini dapat dibuktikan dengan jam kerja guru yang tidak sesuai ketentuan 37,5 jam perminggu.

Indikasi kurangnya motivasi kerja guru dapat dilihat dari beberapa guru yang berada di sekolah hanya ada sesuai jadwal pada sekolah itu. Guru mengajar tanpa menggunakan RPP, atau membuat RPP hanya untuk memenuhi persyaratan administrasi saja. Selain itu, banyak guru yang pangkat golongan ruangnya berada di golongan IV A. Alasannya karena guru tidak termotivasi untuk membuat karya ilmiah dan guru tidak melengkapi persyaratanpersyaratan kompetensi profesionalnya. Kondisi ini merupakan dampak dari ren- 
dahnya motivasi kerja guru di Kecamatan Ketanggungan.

Dari uraian di atas nampak bahwa budaya kerja guru, komitmen guru, dan motivasi kerja guru bersinergi untuk menciptakan iklim organisasi yang kondusif. Semakin baik budaya kerja guru akan semakin meningkatkan komitmen guru dan motivasi kerja guru yang ditandai dengan kondusifnya iklim organisasi sekolah tersebut.

Dalam mewujudkan harapan tersebut, penelitian ini diarahkan pada upaya mengetahui pengaruh antara budaya kerja guru, komitmen guru, dan motivasi kerja guru dalam usaha mewujudkan iklim organisasi sekolah yang kondusif di Kecamatan Ketanggungan Kabupaten Brebes. Oleh karena itu dalam penelitian ini peneliti mengambil judul "Pengaruh Budaya Kerja Guru, Komitmen Guru, dan Motivasi Kerja Guru terhadap Iklim Organisasi Sekolah Dasar di Kecamatan Ketanggungan Kabupaten Brebes".

Berkaitan dengan iklim organisasi sekolah, Steers (1985, p. 121) menyebutkan bahwa iklim organisasi dapat dipandang sebagai kepribadian organisasi seperti yang dilihat oleh para anggotanya". Iklim organisasi tertentu adalah iklim yang dilihat pekerjanya, tidak selalu iklim yang sebenarnya dan iklim yang muncul dalam organisasi merupakan faktor pokok yang menentukan perilaku pekerja.

Tagiuri \& Litwin (Wirawan, 2008, p. 121) mendefinisikan iklim organisasi sebagai bentuk kualitas lingkungan internal organisasi yang secara relatif berlangsung, dialami oleh anggota organisasi, mempengaruhi perilaku anggotanya dan dapat digambarkan dalam pengertian satu set karakteristik atau sifat organisasi.

Sedangkan Lunenburg \& Ornstein (2000, pp. 73-74) mengemukakan bahwa iklim organisasi ialah suatu kualitas lingkungan total dalam suatu organisasi yang ditunjukkan dengan bermacam-macam sifat antara lain: terbuka, sibuk, hangat, santai, informal, dingin, impersonal, bermusuhan, kaku, dan tertutup. Perilaku dalam organisasi bukan hanya fungsi formal kebutuhan dan motivasi individu. Suatu organisasi harus dapat memperhatikan penilaian atau tanggapan anggota organisasi mengenai pentingnya aspek-aspek hubungan kerja dalam membentuk nilai-nilai organisasi.

Iklim dapat dirasakan, tapi tidak dapat disentuh. Iklim juga dipengaruhi oleh hampir semua hal yang terjadi dalam suatu organisasi. Jika organisasi ingin berhasil dalam mewujudkan cita-cita dan tujuannya secara utuh dan sempurna, maka dibutuhkan individu-individu yang handal sebagai sumber daya yang akan memegang kendali organisasi. Agar sumber daya manusia di dalam organisasi dapat bekerja secara optimal dan memiliki loyalitas yang tinggi maka organisasi harus dapat menciptakan iklim yang baik dan menyenangkan.

Selanjutnya, Davis dan Newstrom (1985, p. 46) menyebutkan bahwa budaya kerja memberikan identitas pegawainya, budaya juga sebagai sumber stabilitas serta kontinuitas organisasi yang memberikan rasa aman bagi pegawainya, dan yang lebih penting adalah budaya membantu merang-sang pegawai untuk antusias akan tugas-nya. Sedangkan tujuan fundamental buda-ya adalah untuk membangun sumber daya manusia seutuhnya agar setiap orang sadar bahwa mereka berada dalam suatu hubungan sifat peran sebagai pelanggan dalam komunikasi dengan orang lain secara efektif dan efisien serta menggembirakan.

Sedangkan Kausal (2010, p. 319) mengatakan budaya kerja mengacu pada pola dasar asumsi bersama, nilai-nilai, dan keyakinan yang menentukan cara karyawan berpikir dan bertindak atas masalah dan peluang dalam sebuah organisasi.

Supriyadi \& Triguno (Organisasi. Org, 2007) mengatakan budaya kerja adalah suatu falsafah dengan didasari pandangan hidup sebagai nilai-nilai yang menjadi sifat, kebiasaan dan juga pendorong yang dibudayakan dalam suatu kelompok dan tercermin dalam sikap menjadi perilaku, cita-cita, pendapat, pandangan serta tindakan yang terwujud sebagai kerja. 
Budaya kerja mempunyai arti yang sangat mendalam, karena dapat merubah sikap dan perilaku manusia dalam suatu kelompok untuk mencapai produktivitas kerja yang selalu mendasari nilai-nilai filosofi yang penuh makna, sehingga menjadi motivasi, memberi inspirasi, untuk senantiasa bekerja lebih baik.

Komitmen pegawai menurut Kanter (dalam Angle \& Perry, 1981, p. 1) didefinisikan sebagai kesediaan pelaku sosial untuk memberikan energi dan kesetiaan mereka kepada sistem sosial.

Wuradji (2009, p. 48) komitmen merupakan "kesediaan mematuhi aturanaturan atau apa saja yang telah menjadi kesepakatan bersama". Secara umum komitmen kerja melibatkan keterikatan individu terhadap pekerjaannya.

Komitmen kerja merupakan sebuah variabel yang mencerminkan derajat hubungan yang dianggap dimiliki oleh individu terhadap pekerjaan tertentu dalam organisasi. Greenberg dan Baron (2003: 162) mengemukakan bahwa komitmen kerja merefleksikan tingkat identifkasi dan keterlibatan individu dalam pekerjaannya dan ketidaksediaannya untuk meninggalkan pekerjaan tersebut.

Sedangkan Spencer \& Spencer (Sudarmanto, 2009, p. 102) mengemukakan "komitmen organisasi adalah kemampuan individu dan kemauan menyelaraskan perilakunya dengan kebutuhan, prioritas dan tujuan organisasi dan bertindak untuk tujuan atau kebutuhan organisasi." Berdasarkan definisi tersebut anggota organisasi yang memiliki komitmen akan berusaha mengerahkan kemampuan dan perilakunya untuk memenuhi kebutuhan organisasi.

Usman (2013, p. 276) mengatakan bahwa "motivasi merupakan keinginan yang terdapat pada seseorang individu yang merangsangnya untuk melakukan tindakan-tindakan atau sesuatu yang menjadi dasar atau ulasan seseorang berperilaku".

Sementara Hersey \& Blanchard (1982, p. 15) mengatakan motif kadang-kadang didefinisikan sebagai kebutuhan keingin- an, arahan atau dorongan dalam diri individu. Motif diarahkan ke arah tujuan, yang mungkin disadari ataupun tidak disadari oleh individu tersebut.

Robbins (2006, p. 213) mendefinisikan "motivasi sebagai proses yang ikut menentukan intensitas, arah, dan ketekunan individu dalam usaha mencapai sasaran".

\section{Metode Penelitian}

Jenis, Waktu, dan Penelitian

Penelitian ini merupakan penelitian survei tentang iklim organisasi sekolah dan factor-faktor yang mempengaruhi di SD Kecamatan Ketanggungan. Di dalam penelitian ini pendekatan yang digunakan adalah pendekatan kuantitatif.

Penelitian dilaksanakan di wilayah kerja UPTD Pendidikan Kecamatan Ketanggungan, Kabupaten Brebes. Kegiatan penelitian dilaksanakan selama 4 bulan, mulai bulan Oktober 2013 sampai bulan Januari 2014.

\section{Populasi dan Sampel Penelitian}

Populasi dalam penelitian ini adalah seluruh SD di Kecamatan Ketanggungan, Kabupaten Brebes berjumlah 55 SD.

Sampel penelitian 48 SD yang dipilih dengan teknik simple random sampling, adapun narasumber/responden adalah 144 guru yang dipilih dengan menggunakan teknik stratified random sampling dengan mengambil 3 guru dari kelas 1 (satu) sampai kelas 6 (enam).

Variabel Penelitian

Variabel Terikat (Dependent Variable)

Iklim Organisasi Sekolah (Y)

Iklim organisasi merupakan sebuah konsep yang menggambarkan suasana internal lingkungan organisasi yang dirasakan oleh anggotanya selama beraktivitas dalam rangka tercapainya tujuan organisasi.

Konsep ini berkaitan dengan: (1) keleluasaan guru dalam menyesuaikan diri terhadap tugas-tugas, (2) perasaan guru 
mengenai pelaksanaan tugas organisasi yang diembannya, (3) perasaan guru tentang kondisi organisasi, (4) perasaan guru tentang penghargaan dan pengakuan atas pekerjaan yang baik, (5) perasaan guru akan keterlibatan dalam pekerjaan, peranan dan tujuan organisasi, (6) perasaan guru mengenai perasaan bangga memiliki organisasi, (7) kerja sama antara, kepala sekolah, guru, siswa, dan komite sekolah.

\section{Variabel bebas (Independent Variable)}

\section{Budaya Kerja Guru (X1)}

Budaya kerja adalah cara pandang yang menumbuhkan keyakinan atas dasar nilai-nilai yang diyakini guru untuk mewujudkan prestasi kerja terbaik dengan indikator sebagai berikut.

Pertama, kejujuran menunjukkan sikap guru terhadap kejujuran di tempat kerja dengan kriteria: (a) budaya jujur dalam setiap kata dan perbuatan dengan penuh tanggung jawab dalam melaksanakan tugas; (b) budaya pemberian penghargaan bagi guru yang jujur.

Kedua, ketekunan menunjukkan perilaku guru terhadap ketekunan di tempat kerja dengan kriteria: (a) budaya teliti, rajin mendalami sesuatu pekerjaan atau tugas yang secara konsisten dan berkelanjutan; (b) budaya perhatian terhadap hal-hal kecil dalam pekerjaan.

Ketiga, kreativitas menunjukkan perilaku guru terhadap kreativitas di tempat kerja dengan kriteria: (a) budaya menciptakan ide-ide baru dalam pekerjaan; (b) budaya memberikan penghargaan kepada guru yang kreatif; (c) budaya menghadirkan aneka solusi tepat mengatasai masalah dalam pelaksanaan tugas.

Keempat, kedisiplinan menunjukkan perilaku guru terhadap kedisiplinan di tempat kerja dengan kriteria: (a) budaya sikap untuk tidak menentang aturan-aturan dan norma yang berlaku; (b) budaya penegakan hukum dengan sanksi yang tegas.

Kelima, IPTEK menunjukkan sikap dan perilaku guru terhadap iptek di tempat kerja dengan kriteria: (a) budaya penguasaan iptek merupakan suatu hal yang harus dimiliki setiap guru guna mempercepat tugas pelayanan; (b) pemanfaatan kemajuan ilmu pengetahuan dan teknologi guna mempercepat tugas pelayanan.

\section{Komitmen guru (X2)}

Komitmen adalah rasa keterikatan yang kuat antara guru terhadap falsafah dan satuan kerja sehingga guru rela melaksanakan tugas yang harus diemban secara taat asas, yang telah ditetapkan dalam satu wadah kerjasama untuk mencapai tujuan tertentu berdasarkan nilai-nilai yang dipegang teguh bersama, dengan indikator yaitu: (1) kesediaan diri guru mengerahkan seluruh usaha yang diharapkan untuk menyelesaikan tugas dan kewajiban; (2) merekomendasikan hal-hal positif kepada guru lain; (3) memegang teguh visi dan misi dan melaksanakannya dengan taat asas dalam tugas sehari-hari.

\section{Motivasi Kerja Guru (X3)}

Motivasi kerja guru yaitu dorongan dari dalam diri untuk mengatasi segala tantangan dan hambatan, serta berhubungan dengan orang lain dalam upaya mencapai tujuan. Hal ini ditandai dengan: (1) bertanggung jawab atas segala perbuatan, (2) tidak menyalahkan orang lain dalam kegagalan, (3) bersedia mendengarkan pendapat orang lain sebagai masukan dalam memperbaiki dirinya, (4) berani mengambil resiko dengan penuh perhitungan (menantang dan terwujud) melebihi orang lain, (5) berusaha melakukan sesuatu secara inovatif dan kreatif, banyak gagasan dan mampu mewujudkan gagasannya dengan baik, (6) bekerja keras dan bangga atas hasil yang telah dicapai, (7) lebih suka bekerjasama dengan orang lain, (8) sering berkomunikasi dengan orang lain, (9) selalu bermusyawarah untuk mufakat dengan orang lain, (10) aktif dalam menentukan arah kegiatan organisasi.

Dari kriteria tersebut, dibuat skor menggunakan rating scale, kemudian dikelompokkan menggunakan distribusi frekuensi berdasarkan kelas interval dan diberi kriteria menyesuaikan jenis instrumen 
yang disediakan dari banyaknya, tingginya, atau seringnya.

\section{Teknik Pengumpulan Data}

Teknik pengumpulan data dalam penelitian ini yaitu kuisioner yang menggunakan pernyataan tertutup dengan validitas item yang mendapat pertimbangan ahli dan uji empirik, sedangkan reliabilitas instrumen dengan teknik Alpha_Cronbach.

Adapun pengambilan keputusan pada uji validitas dengan menggunakan batasan $\mathrm{r}$ tabel, dengan signifikansi 0,05 atau menggunakan batasan 0,312 pada $\mathrm{n}=$ 41. Hasil uji validitas instrumen variabel iklim organisasi sekolah dari jumlah 22 item pertanyaan angket menunjukkan 20 item yang dianggap valid, instrumen variabel budaya kerja guru dari 31 item pertanyaan angket menunjukkan 30 item dinyatakan valid, kemudian instrumen variabel komitmen guru dari 12 item pertanyaan angket menunjukkan 11 item dinyatakan valid, dan variabel motivasi kerja guru dari 20 item pertanyaan angket menunjukkan 18 item dinyatakan valid.

Selanjutnya untuk uji reliabilitas, harga kritik untuk indeks reliabilitas instrumen adalah 0,7 hal ini berarti suatu instrumen dikatakan reliabel apabila memiliki alpha $>0,7$. Adapun hasil reliabiltas instrumen adalah sebagai berikut:

Tabel 1. Hasil Reliabilitas Instrumen

\begin{tabular}{lcc}
\hline Variabel & $\begin{array}{c}\text { Cronbach's } \\
\text { Alpha }\end{array}$ & Ket. \\
\hline Iklim Organisasi Sekolah & 0,829 & Reliable \\
Budaya Kerja Guru & 0,892 & Reliable \\
Komitmen Guru & 0,744 & Reliable \\
Motivasi Kerja Guru & 0,840 & Reliable \\
\hline
\end{tabular}

Tabel 1 menunjukkan bahwa semua instrumen dinyatakan reliabel. Untuk itu semua instrumen yang dinyatakan valid dan reliabel sudah layak digunakan untuk mengambil data.

Teknis Analisis Data

\section{Analisis Data Deskriptif}

Untuk memberi deskripsi mengenai data penelitian, maka digunakan uji analisis deskripsi yang bertujuan untuk meng- analisis data dengan cara mendeskripsikan atau menggambarkan data yang terkumpul, sebagaimana adanya. Analisis deskriptif ini digunakan untuk mendapatkan gambaran penyebaran hasil data hasil penelitian masing-masing variabel secara kategorial. Analisis deskripsi menyangkut banyaknya subyek dalam kelompok, mean skor angket, deviasi standar skor angket, varians, skor maksimum, dan skor minimum.

\section{Uji Hipotesis}

Uji regresi sederhana untuk mengetahui pengaruh masing-masing variabel prediktor yang mempengaruhi budaya kerja guru (X1) komitmen guru $\left(X_{2}\right)$ dan motivasi kerja guru (X3) terhadap iklim organisasi sekolah $(\mathrm{Y})$ dengan menggunakan regresi, yaitu :

$$
\hat{Y}=a+b X
$$

Keterangan :

$$
\begin{aligned}
& \mathrm{Y}=\text { nilai yang diprediksi } \\
& \mathrm{X}=\text { nilai variabel prediktor } \\
& \mathrm{a}=\text { bilangan konstan } \\
& \mathrm{b}=\text { bilangan koefisien prediktor }
\end{aligned}
$$

\section{Hasil Penelitian dan Pembahasan}

\begin{tabular}{|c|c|c|c|c|c|}
\hline \multicolumn{6}{|c|}{ Statistics } \\
\hline & & erja Guru & en Guru I & erja Guru & Sekolah \\
\hline \multirow[t]{2}{*}{$\mathrm{N}$} & Valid & 48 & 48 & 48 & 48 \\
\hline & Missing & 0 & 0 & 0 & 0 \\
\hline \multicolumn{2}{|c|}{ Mean } & 367.44 & 149.13 & 250.40 & 266.81 \\
\hline \multicolumn{2}{|c|}{ Median } & 361.00 & 148.50 & 251.50 & 266.50 \\
\hline \multicolumn{2}{|c|}{ Mode } & $360^{8}$ & 146 & $247^{\mathrm{a}}$ & $254^{\mathrm{a}}$ \\
\hline \multicolumn{2}{|c|}{ Std. Deviation } & 23.232 & 9.664 & 15.683 & 12.561 \\
\hline \multicolumn{2}{|c|}{ Variance } & 539.741 & 93.388 & 245.946 & 157.773 \\
\hline \multicolumn{2}{|c|}{ Range } & 105 & 42 & 85 & 57 \\
\hline \multicolumn{2}{|c|}{ Minimum } & 315 & 126 & 191 & 238 \\
\hline \multicolumn{2}{|c|}{ Maximum } & 420 & 168 & 276 & 295 \\
\hline \multicolumn{2}{|c|}{ Sum } & 17637 & 7158 & 12019 & 12807 \\
\hline & & nalle & showr & & \\
\hline
\end{tabular}

Analisis Deskriptif Variabel Penelitian

Temuan penelitian menunjukkan hasil sebagaimana disajikan pada Tabel 2 .

Tabel 2. Rangkuman Deskripsi Data

Tabel 2. menunjukkan bahwa variabel Budaya Kerja Guru diperoleh mean sebesar 367,44 dengan standar deviasi sebesar 23,232. Variabel Komitmen Guru diperoleh mean sebesar 149,13 dengan 
standar deviasi sebesar 9,664, dan variabel motivasi kerja guru diperoleh mean sebesar 250,40 dengan standar deviasi sebesar 15,683 , serta variabel iklim organisasi sekolah diperoleh mean 266,81 dengan standar deviasi sebesar 12,561. Secara rinci dengan distribusi frekuensi deskripsi masing-masing variabel dijelaskan sebagai berikut:

\section{Budaya Kerja Guru}

Budaya kerja guru di Sekolah Dasar Kecamatan Ketanggungan Kabupaten Brebes adalah salah satu variabel dengan indikator budaya kejujuran, ketekunan, kreativitas, kedisiplinan dan budaya iptek yang diduga memiliki peran dalam membentuk iklim organisasi sekolah yang baik. Pengelompokkan data budaya kerja guru di Sekolah Dasar Kecamatan Ketanggungan Kabupaten Brebes secara rinci dapat dilihat berikut ini:

Tabel 3. Hasil Analisis Deskriptif Budaya Kerja Guru

\begin{tabular}{ccccc}
\hline No & Interval & Kriteria & Frekuensi & Persentase \\
\hline 1 & $403-420$ & Sangat baik & 3 & $6,25 \%$ \\
\hline 2 & $381-402$ & Baik & 16 & $33,33 \%$ \\
\hline 3 & $359-380$ & Cukup baik & 13 & $27,08 \%$ \\
\hline 4 & $337-358$ & Kurang baik & 13 & $27,08 \%$ \\
\hline 5 & $315-336$ & Tidak Baik & 3 & $6,25 \%$ \\
\hline \multicolumn{7}{r}{ Jumlah } & & 48 & $100 \%$ \\
\hline
\end{tabular}

Berdasarkan Tabel 3, mean atau skor rata-rata sebesar 367.44 terletak pada interval 359-380 dalam kategori cukup baik. Hal ini mengandung arti bahwa kecenderungan jawaban responden secara keseluruhan mengarah pada tingkatan cukup baik, dengan demikian, secara keseluruhan budaya kerja guru di Sekolah Dasar Kecamatan Ketanggungan Kabupaten Brebes dalam kategori cukup baik.

\section{Komitmen Guru}

Pengelompokan data komitmen guru di Sekolah Dasar Kecamatan Ketanggungan Kabupaten Brebes secara rinci disajikan pada Tabel 4 .

Tabel 4. Menunjukkan bahwa mean atau skor rata-rata sebesar 149.13 terletak pada interval 144-152 dalam kategori cukup baik, dengan demikian komitmen guru di Sekolah Dasar Kecamatan Ketanggungan Kabupaten Brebes adalah cukup baik. Hal ini mengandung arti bahwa kecenderungan jawaban responden secara keseluruhan mengarah pada tingkatan $\mathrm{cu}-$ kup baik, dengan demikian, secara keseluruhan komitmen guru di Sekolah Dasar Kecamatan Ketanggungan Kabupaten Brebes dalam kategori cukup baik.

Tabel 4. Hasil Analisis Deskriptif Komitmen Guru

\begin{tabular}{ccccc}
\hline No & Interval & Kriteria & Frekuensi & Persentase \\
\hline 1 & $162-168$ & Sangat baik & 5 & $10,42 \%$ \\
\hline 2 & $153-161$ & Baik & 11 & $22,92 \%$ \\
\hline 3 & $144-152$ & Cukup baik & 20 & $41,67 \%$ \\
\hline 4 & $135-143$ & Kurang baik & 10 & $20,83 \%$ \\
\hline 5 & $126-134$ & Tidak Baik & 2 & $4,17 \%$ \\
\hline & Jumlah & & 48 & $100 \%$ \\
\hline
\end{tabular}

Motivasi Kerja Guru

Pengelompokan data motivasi kerja guru di Sekolah Dasar Kecamatan Ketanggungan Kabupaten Brebes disajikan pada Tabel 5.

Tabel 5. Hasil Analisis Deskriptif Komitmen Guru

\begin{tabular}{|c|c|c|c|c|}
\hline No & Interval & Kriteria & Frekuensi & Persentase \\
\hline 1 & $263-276$ & Sangat baik & 10 & $20,83 \%$ \\
\hline 2 & $245-262$ & Baik & 28 & $58,33 \%$ \\
\hline 3 & $227-244$ & Cukup baik & 6 & $12,50 \%$ \\
\hline 4 & $209-226$ & Kurang baik & 3 & $6,25 \%$ \\
\hline 5 & $191-208$ & Tidak Baik & 1 & $2,08 \%$ \\
\hline \multicolumn{3}{|c|}{ Jumlah } & 48 & $100 \%$ \\
\hline
\end{tabular}

Tabel 5 menunjukkan bahwa mean atau skor rata-rata variabel motivasi kerja guru sebesar 250.40 terletak pada interval 245-262 dalam kategori baik, dengan demikian motivasi kerja guru di Sekolah Dasar Kecamatan Ketanggungan Kabupaten Brebes adalah baik. Hal ini mengandung arti bahwa kecenderungan jawaban responden secara keseluruhan mengarah pada tingkatan baik, dengan demikian, motivasi kerja guru di Sekolah Dasar Kecamatan Ketanggungan Kabupaten Brebes secara keseluruhan dalam kategori baik. 
Iklim Organisasi Sekolah

Pengelompokan data iklim organisasi sekolah di Sekolah Dasar Kecamatan Ketanggungan Kabupaten Brebes dapat dilihat secara rinci berikut ini:

Tabel 6. Hasil Analisis Deskriptif Iklim Organisasi Sekolah

\begin{tabular}{|c|c|c|c|c|}
\hline No & Interval & Kriteria & Frekuensi & Persentase \\
\hline 1 & $286-296$ & Sangat baik & 3 & $6,25 \%$ \\
\hline 2 & $274-285$ & Baik & 9 & $18,75 \%$ \\
\hline 3 & $262-273$ & Cukup baik & 16 & $33,33 \%$ \\
\hline 4 & $250-261$ & Kurang baik & 18 & $37,50 \%$ \\
\hline 5 & $238-249$ & Tidak Baik & 2 & $4,17 \%$ \\
\hline \multicolumn{3}{|c|}{ Jumlah } & 48 & $100 \%$ \\
\hline
\end{tabular}

Tabel 2 dan Tabel 6 menunjukkan bahwa mean atau skor rata-rata variabel iklim organisasi sekolah sebesar 266.81 terletak pada interval 262-273 dalam kategori cukup baik, dengan demikian iklim organisasi sekolah di Sekolah Dasar Kecamatan Ketanggungan Kabupaten Brebes adalah cukup baik. Hal ini mengandung arti bahwa kecenderungan jawaban responden secara keseluruhan mengarah pada tingkatan cukup baik, dengan demikian, iklim organisasi sekolah di Sekolah Dasar Kecamatan Ketanggungan Kabupaten Brebes secara keseluruhan dalam kategori cukup baik.

Rangkuman hasil pengkategorian keempat variabel tersebut disajikan pada Tabel 7.

Tabel 7. Hasil Analisis Deskriptif Persentase Keempat Variabel Penelitian

\begin{tabular}{ccccccc}
\hline & & \multicolumn{5}{c}{ Kriteria } \\
No & Varsentase, \%) \\
\cline { 3 - 7 } & & $\begin{array}{c}\text { Sangat } \\
\text { Baik }\end{array}$ & Baik & $\begin{array}{c}\text { Cukup } \\
\text { Baik }\end{array}$ & $\begin{array}{c}\text { Kurang } \\
\text { Baik }\end{array}$ & $\begin{array}{c}\text { Tidak } \\
\text { Baik }\end{array}$ \\
\hline 1 & Budaya Kerja Guru & 6,25 & 33,33 & 27,08 & 27,08 & 6,25 \\
\hline 2 & Komitmen Guru & 10,42 & 22,92 & 41,67 & 20,83 & 4,17 \\
\hline 3 & Motivasi Kerja Guru & 20,83 & 58,33 & 12,50 & 6,25 & 2,08 \\
\hline 4 & Iklim Organisasi Sekolah & 6,25 & 18,75 & 33,33 & 37,50 & 4,17 \\
\hline
\end{tabular}

Tabel 7 menunjukkan bahwa budaya kerja guru berada pada kriteria baik yaitu $33,33 \%$. Hal ini mengandung arti secara keseluruhan mengarah pada tingkatan baik. Komitmen guru berada pada kriteria cukup baik yaitu 41,67\%, motivasi kerja guru berada pada kriteria baik yaitu
58,33\% dan iklim organisasi sekolah berada pada kriteria baik.

\section{Uji Hipotesis Pertama}

Ho: tidak ada pengaruh yang signifikan budaya kerja guru terhadap iklim organisasi sekolah

Ha: ada pengaruh yang signifikan budaya kerja guru terhadap iklim organisasi sekolah

Analisis pengujian hipotesis menggunakan regresi linier sederhana. Hasil analisis meliputi uji kelayakan model koefisien regresi. Pengambilan keputusan menggunakan taraf signifikansi $p<0,05$. Sebuah model dan koefisien regresi dinyatakan signifikan jika memiliki nilai $\mathrm{p}<0,05$. Hasil uji kelayakan model regresi disajikan pada Tabel 8.

Tabel 8. Hasil Uji Model Regresi Hipotesis 1

\begin{tabular}{|c|c|c|c|c|c|c|}
\hline \multicolumn{7}{|c|}{ ANOVA $^{p}$} \\
\hline \multicolumn{2}{|c|}{ Model } & $\begin{array}{l}\text { Sum of } \\
\text { Squares }\end{array}$ & Df & $\begin{array}{l}\text { Mean } \\
\text { Square }\end{array}$ & $\mathrm{F}$ & Sig. \\
\hline \multirow[t]{3}{*}{1} & Regression & 1473.530 & 1 & 1473.530 & 11.408 & $.001^{\mathrm{a}}$ \\
\hline & Residual & 5941.783 & 46 & 129.169 & & \\
\hline & Total & 7415.313 & 47 & & & \\
\hline \multicolumn{7}{|c|}{ a. Predictors: (Constant), Budaya Kerja Guru } \\
\hline \multicolumn{7}{|c|}{ b. Dependent Variable: Iklim Organisasi Sekolah } \\
\hline
\end{tabular}

Berdasarkan hasil uji anova pada Tabel 8 di atas, dihasilkan F hitung $=11,408$ dan sig. $=0,001$. Oleh karena $p<0,05$, maka diputuskan bahwa model regresi signifikan dan dapat digunakan untuk memprediksi budaya kerja guru di Sekolah Dasar Kecamatan Ketanggungan Kabupaten Brebes.

Besarnya pengaruh budaya kerja guru terhadap iklim organisasi sekolah dapat dilihat pada output komputer yang disajikan pada Tabel 9.

Tabel 9. Hasil Uji Model Summary Hipotesis 1

\begin{tabular}{|c|c|c|c|c|c|c|c|c|c|}
\hline \multicolumn{10}{|c|}{ Model Summary ${ }^{\circ}$} \\
\hline \multirow[b]{2}{*}{ Model } & \multirow[b]{2}{*}{$R$} & \multirow[b]{2}{*}{$\begin{array}{c}R \\
\text { Square }\end{array}$} & \multirow[b]{2}{*}{$\begin{array}{l}\text { Adjusted R } \\
\text { Square }\end{array}$} & \multirow{2}{*}{$\begin{array}{l}\text { Std. Error } \\
\text { of the } \\
\text { Estimate }\end{array}$} & \multicolumn{5}{|c|}{ Change Statistics } \\
\hline & & & & & $\begin{array}{l}R \text { Square } \\
\text { Change } \\
\end{array}$ & $\begin{array}{c}\mathrm{F} \\
\text { Change } \\
\end{array}$ & df1 & $\mathrm{df} 2$ & $\begin{array}{c}\text { Sig. F } \\
\text { Change }\end{array}$ \\
\hline 1 & $.446^{2}$ & .199 & .181 & 11.365 & .199 & 11.408 & 1 & 46 & .001 \\
\hline \multicolumn{10}{|c|}{ a. Predictors: (Constant), Budaya Kerja Guru } \\
\hline \multicolumn{10}{|c|}{ b. Dependent Variable: IKlim Organisasi Sekolah } \\
\hline
\end{tabular}


Berdasarkan output komputer Tabel 9 dapat dijelaskan bahwa diperoleh nilai Adjusted R square sebesar 0,181 . Hal ini berarti bahwa variabel budaya kerja guru berpengaruh terhadap iklim organisasi sekolah sebesar $18,1 \%$ dan sisanya sebesar $81,9 \%$ ditentukan oleh sebab lain di luar model tersebut. Oleh karena itu dapat disimpulkan bahwa terdapat pengaruh yang signifikan budaya kerja guru terhadap iklim organisasi sekolah di Sekolah Dasar Kecamatan Ketanggungan Kabupaten Brebes.

\section{Uji Hipotesis Kedua}

Ho: tidak ada pengaruh yang signifikan komitmen guru terhadap iklim organisasi sekolah.

Ha: ada pengaruh yang signifikan komitmen guru terhadap iklim organisasi sekolah.

Analisis pengujian hipotesis menggunakan regresi linier sederhana. Hasil analisis meliputi uji kelayakan model koefisien regresi. Pengambilan keputusan menggunakan taraf signifikansi $p<0,05$. Sebuah model dan koefisien regresi dinyatakan signifikan jika memiliki nilai $\mathrm{p}<0,05$. Hasil uji kelayakan model regresi disajikan pada Tabel 10.

Tabel 10. Hasil Uji Model Regresi Hipotesis 2

\begin{tabular}{|c|c|c|c|c|c|c|}
\hline \multicolumn{7}{|c|}{ ANOVA $^{\circ}$} \\
\hline Model & & Sum of Squares & Df & Mean Square & $\mathrm{F}$ & Sig. \\
\hline \multirow[t]{3}{*}{1} & Regression & 1238.057 & 1 & 1238.057 & 9.219 & $.004^{a}$ \\
\hline & Residual & 6177.255 & 46 & 134.288 & & \\
\hline & Total & 7415.313 & 47 & & & \\
\hline \multicolumn{7}{|c|}{ a. Predictors: (Constant), Komitmen Guru } \\
\hline D & 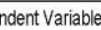 & Orga & & & & \\
\hline
\end{tabular}

Berdasarkan hasil uji anova pada Tabel 10 di atas, dihasilkan $\mathrm{F}$ hitung $=9,219$ dan sig. $=0,004$. Oleh karena $p<0,05$, maka diputuskan bahwa model regresi signifikan dan dapat digunakan untuk memprediksi komitmen guru di Sekolah Dasar Kecamatan Ketanggungan Kabupaten Brebes.

Besarnya komitmen guru terhadap iklim organisasi sekolah dapat dilihat pada Tabel 11.
Tabel 11. Hasil Uji Model Summary Hipotesis 2

\begin{tabular}{|c|c|c|c|c|c|c|c|c|c|}
\hline \multicolumn{10}{|c|}{ Model Summary ${ }^{\circ}$} \\
\hline \multirow[b]{2}{*}{ Model } & \multirow[b]{2}{*}{$\mathrm{R}$} & \multirow[b]{2}{*}{$\begin{array}{c}\mathrm{R} \\
\text { Square }\end{array}$} & & \multirow{2}{*}{$\begin{array}{l}\text { Std. Error } \\
\text { of the }\end{array}$} & \multicolumn{5}{|c|}{ Change Statistics } \\
\hline & & & $\begin{array}{l}\text { Adjusted } \\
\text { R Square }\end{array}$ & & $\begin{array}{l}\text { R Square } \\
\text { Change }\end{array}$ & $\begin{array}{c}F \\
\text { Change }\end{array}$ & df1 & df2 & $\begin{array}{c}\text { Sig. F } \\
\text { Change }\end{array}$ \\
\hline 1 & $.409^{9}$ & .167 & .149 & 11.588 & .167 & 9.219 & 1 & 46 & .004 \\
\hline \multicolumn{10}{|c|}{ a. Predictors: (Constant), Komitmen Guru } \\
\hline b. Dep & endent & t Variable & e: Iklim Orga & anisasi Sek & olah & & & & \\
\hline
\end{tabular}

Berdasarkan output komputer Tabel 11 dapat dijelaskan bahwa diperoleh nilai Adjusted R square sebesar 0,149. Hal ini berarti bahwa variabel komitmen guru berpengaruh terhadap iklim organisasi sekolah sebesar $14,9 \%$ dan sisanya sebesar $85,1 \%$ ditentukan oleh sebab lain di luar model tersebut. Oleh karena itu dapat disimpulkan bahwa terdapat pengaruh yang signifikan komitmen guru terhadap iklim organisasi sekolah di Sekolah Dasar Kecamatan Ketanggungan Kabupaten Brebes.

\section{Uji Hipotesis Ketiga}

Ho: tidak ada pengaruh yang signifikan motivasi kerja guru terhadap iklim organisasi sekolah

Ha: ada pengaruh yang signifikan motivasi kerja guru terhadap iklim organisasi sekolah

Analisis pengujian hipotesis menggunakan regresi linier sederhana. Hasil analisis meliputi uji kelayakan model koefisien regresi. Pengambilan keputusan menggunakan taraf signifikansi $p<0,05$. Sebuah model dan koefisien regresi dinyatakan signifikan jika memiliki nilai $p<0,05$. Hasil uji kelayakan model regresi disajikan pada Tabel 12.

Tabel 12. Hasil Uji Model Regresi Hipotesis 3

\begin{tabular}{|c|c|c|c|c|c|c|}
\hline \multicolumn{7}{|c|}{ ANOVA $^{b}$} \\
\hline Mad & & Sum of Squares & Df & Mean Square & $\mathrm{F}$ & Sig. \\
\hline \multirow[t]{3}{*}{1} & Regression & 747.527 & 1 & 747.527 & 5.157 & $.028^{8}$ \\
\hline & Residual & 6667.785 & 46 & 144.952 & & \\
\hline & Total & 7415.313 & 47 & & & \\
\hline \multicolumn{7}{|c|}{ a. Predictors: (Constant), Motivasi Kerja Guru } \\
\hline \multicolumn{7}{|c|}{ b. Dependent Variable: Iklim Organisasi Sekolah } \\
\hline
\end{tabular}

Berdasarkan hasil uji anova pada Tabel 12, dihasilkan $\mathrm{F}$ hitung $=5,157$ dan 
sig. $=0,028$. Oleh karena $\mathrm{p}<0,05$, maka diputuskan bahwa model regresi signifikan dan dapat digunakan untuk memprediksi motivasi kerja guru di Sekolah Dasar Kecamatan Ketanggungan Kabupaten Brebes.

Besarnya motivasi kerja guru terhadap iklim organisasi sekolah disajikan pada Tabel 13.

Tabel 13. Hasil Uji Model Summary Hipotesis 3

\begin{tabular}{|c|c|c|c|c|c|c|c|c|c|}
\hline \multicolumn{10}{|c|}{ Model Summary } \\
\hline \multirow[b]{2}{*}{ Model } & \multirow[b]{2}{*}{$\mathrm{R}$} & \multirow[b]{2}{*}{ R Square } & \multirow[b]{2}{*}{$\begin{array}{l}\text { Adjusted R } \\
\text { Square }\end{array}$} & Std. Error & \multicolumn{4}{|c|}{ Change Statistics } & \multirow[b]{2}{*}{$\begin{array}{l}\text { Sig. F } \\
\text { Change }\end{array}$} \\
\hline & & & & $\begin{array}{l}\text { of the } \\
\text { Estimate }\end{array}$ & $\begin{array}{l}\text { R Square } \\
\text { Change }\end{array}$ & $\begin{array}{c}F \\
\text { Change }\end{array}$ & df1 & $\mathrm{df} 2$ & \\
\hline 1 & $.318^{8}$ & .101 & .081 & 12.040 & .101 & 5.157 & & 146 & .028 \\
\hline \multicolumn{10}{|c|}{ a. Predictors: (Constant), Motivasi Kerja Guru } \\
\hline \multicolumn{10}{|c|}{ b. Dependent Variable: Iklim Organisasi Sekolah } \\
\hline
\end{tabular}

Tabel 13 menunjukkan bahwa nilai Adjusted R square sebesar 0,081. Hal ini berarti bahwa variabel motivasi kerja guru berpengaruh terhadap iklim organisasi sekolah sebesar $8,1 \%$ dan sisanya sebesar 91,9\% ditentukan oleh sebab lain di luar model tersebut. Oleh karena itu dapat disimpulkan bahwa terdapat pengaruh yang signifikan motivasi kerja guru terhadap iklim organisasi sekolah di Sekolah Dasar Kecamatan Ketanggungan Kabupaten Brebes.

\section{Uji Hipotesis Keempat}

Ho: tidak ada pengaruh yang signifikan budaya kerja guru, komitmen guru, dan motivasi kerja guru terhadap iklim organisasi sekolah

Ha: ada pengaruh yang signifikan budaya kerja guru, komitmen guru, dan motivasi kerja guru terhadap iklim organisasi sekolah

Analisis pengujian hipotesis menggunakan regresi ganda dengan bantuan program SPSS For Windows17. Kriteria kelayakan model regresi ganda didasarkan ketentuan signifikansi $\mathrm{p}<0,05$. Hasil uji model regresi hipotesis 4 disajikan pada Tabel 14 .

Berdasarkan Tabel 14 dapat dilihat pada model regresi $A N O V A$, nilai $\mathrm{F}$ hitung 12,272 dengan signifikansi $=0,000$. Oleh karena itu dapat diputuskan bahwa model regresi ganda untuk hipotesis 4 dengan prediktor budaya kerja guru, komitmen guru dan motivasi kerja guru telah signifikan.

Tabel 14. Hasil Uji Model Regresi Hipotesis 4

\begin{tabular}{|c|c|c|c|c|c|c|}
\hline \multicolumn{7}{|c|}{ ANOVA $^{\mathrm{b}}$} \\
\hline \multicolumn{2}{|c|}{ Model } & Sum of Squares & Df & Mean Square & $\mathrm{F}$ & Sig. \\
\hline \multirow[t]{3}{*}{1} & Regression & 747.527 & 1 & 747.527 & 5.157 & $.028^{a}$ \\
\hline & Residual & 6667.785 & 46 & 144.952 & & \\
\hline & Total & 7415.313 & 47 & & & \\
\hline \multicolumn{7}{|c|}{ a. Predictors: (Constant), Motivasi Kerja Guru } \\
\hline \multicolumn{7}{|c|}{ b. Dependent Variable: Iklim Organisasi Sekolah } \\
\hline
\end{tabular}

Besarnya pengaruh variabel bebas terhadap variabel terikat telah dianalisis dengan hasil disajikan berikut ini:

Tabel 15. Hasil Uji Model Summary Variabel Bebas terhadap Varibel Terikat

\begin{tabular}{|c|c|c|c|c|c|c|c|c|c|}
\hline \multicolumn{10}{|c|}{ Model Summary ${ }^{b}$} \\
\hline \multirow[b]{2}{*}{ Model } & \multirow[b]{2}{*}{$\mathrm{R}$} & \multirow[b]{2}{*}{$\begin{array}{c}\mathrm{R} \\
\text { Square }\end{array}$} & \multirow[b]{2}{*}{$\begin{array}{l}\text { Adjusted R } \\
\text { Square }\end{array}$} & \multirow{2}{*}{$\begin{array}{l}\text { Std. Error } \\
\text { of the } \\
\text { Estimate }\end{array}$} & \multicolumn{5}{|c|}{ Change Statistics } \\
\hline & & & & & $\begin{array}{l}R \text { Square } \\
\text { Change } \\
\end{array}$ & $\begin{array}{c}F \\
\text { Change } \\
\end{array}$ & df1 & $\mathrm{d}+2$ & $\begin{array}{c}\text { Sig. F } \\
\text { Change }\end{array}$ \\
\hline 1 & $.675^{8}$ & .456 & .418 & 9.579 & .456 & 12.272 & 3 & 44 & .000 \\
\hline \multicolumn{10}{|c|}{ a. Predictors: (Constant), Motivasi Kerja Guru, Komitmen Guru, Budaya Kerja Guru } \\
\hline \multicolumn{10}{|c|}{ b. Dependent Variable: Iklim Organisasi Sekolah } \\
\hline
\end{tabular}

Tabel 15 menunjukkan bahwa besarnya pengaruh variabel bebas meliputi budaya kerja guru, komitmen guru, dan motivasi kerja guru terhadap iklim organisasi sekolah yaitu 0,418 (Adjusted R2). Hal ini berarti ketiga variabel bebas memberi pengaruh sebesar $41,8 \%$ (Adjusted R2) terhadap variabel terikat. Nilai $41,8 \%$ merupakan nilai yang telah disesuaikan dengan jumlah prediktor dalam model. Besar pengaruh tiap variabel bebas terhadap variabel terikat disajikan pada Tabel 16 .

Tabel 16. Besarnya Pengaruh Variabel Bebas terhadap Variabel Terikat

\begin{tabular}{lc}
\hline \multicolumn{1}{c}{ Variabel } & Pengaruh \\
\hline$X_{1} \rightarrow Y$ budaya kerja guru $\rightarrow$ iklim organisasi sekolah & $18,1 \%$ \\
\hline$X_{2} \rightarrow$ Y komitmen guru $\rightarrow$ iklim organisasi sekolah & $14,9 \%$ \\
\hline$X_{3} \rightarrow$ Y motivasi kerja guru $\rightarrow$ iklim organisasi sekolah & $8,1 \%$ \\
\hline
\end{tabular}

Tabel 16 menunjukkan bahwa pengaruh variabel bebas $X_{1}$ terhadap variabel terikat lebih besar dibanding variabel 
bebas lainnya. Variabel budaya kerja guru memberi kontribusi sebesar $18,1 \%$ terhadap iklim organisasi sekolah. Sementara variabel komitmen guru berkontribusi $14,9 \%$ dan variabel motivasi kerja guru berkontribusi paling kecil 8,1\% terhadap iklim organisasi sekolah di Sekolah Dasar Kecamatan Ketanggungan Kabupaten Brebes.

Penelitian ini bertujuan untuk mengetahui: (1) pengaruh budaya kerja guru terhadap iklim organisasi sekolah di Sekolah Dasar Kecamatan Ketanggungan Kabupaten Brebes, (2) pengaruh komitmen guru terhadap iklim organisasi sekolah di Sekolah Dasar Kecamatan Ketanggungan Kabupaten Brebes, (3) pengaruh motivasi kerja guru terhadap iklim organisasi di Sekolah Dasar Kecamatan Ketanggungan Kabupaten Brebes, (4) pengaruh budaya kerja gu$\mathrm{ru}$, komitmen guru dan motivasi kerja guru secara bersama-sama terhadap iklim organisasi sekolah di Sekolah Dasar Kecamatan Ketanggungan Kabupaten Brebes. Berikut ini akan dibahas hasil penelitian sesuai dengan tujuan yang telah ditetapkan:

Pengaruh Budaya Kerja Guru terhadap Iklim Organisasi Sekolah

Berdasarkan hasil uji hipotesis menunjukkan bahwa budaya kerja guru berpengaruh signifikan terhadap iklim organisasi sekolah di Sekolah Dasar Kecamatan Ketanggungan Kabupaten Brebes. Hal ini dapat ditunjukkan dari hasil analisis korelasi parsial diperoleh nilai $r$ sebesar 0,446. Pada taraf signifikansi $\mathrm{p}<0,05$, artinya hubungan variabel budaya kerja guru terhadap iklim organisasi sekolah termasuk pada kategori cukup dan signifikan.

Selanjutnya dari hasil analisis regresi sederhana diperoleh nilai koefisien regresi ke arah positif sebesar 0,241 dengan konstanta 178,256 pada taraf signifikansi $\mathrm{p}<$ 0,05 . Selain itu variabel budaya kerja guru memberi kontribusi sebesar $18,1 \%$ terhadap iklim organisasi sekolah. kontribusi 18,1\% diperoleh dari Adjusted R2, yaitu perolehan nilai yang telah disesuaikan dari adanya residu (kekeliruan tanggapan) responden.
Model estimasi ini tergolong akurat dengan melihat output model summary ${ }^{b}$ dari Std. error of the estimate $<$ Std deviation Y $(11,365<12,561)$. Oleh karena itu dapat disimpulkan bahwa budaya kerja guru memberikan sumbangan yang signifikan terhadap iklim organisasi sekolah di Sekolah Dasar Kecamatan Ketanggungan Kabupaten Brebes.

Budaya kerja guru sekolah dasar di Kecamatan Ketanggungan, Kabupaten Brebes yang tergolong dalam kategori sedang ini terdorong oleh sikap dan perilaku untuk meningkatkan hasil kerja, yang pada gilirannya hasil tersebut menuju suatu situasi/kondisi yaitu terciptanya iklim organisasi sekolah yang kondusif.

Hasil ini sesuai dengan teori yang menyatakan bahwa budaya kerja dapat mengubah sikap dan perilaku guru melalui pola pikir, tingkah laku, dan tatanan kerja serta mekanisme adaptasi terhadap perubahan, menuju terciptanya iklim organisasi sekolah yang baik.

Pengaruh Komitmen Guru terhadap Iklim Organisasi Sekolah

Berdasarkan hasil uji hipotesis menunjukkan bahwa komitmen guru berpengaruh signifikan terhadap iklim organisasi sekolah di Sekolah Dasar Kecamatan Ketanggungan Kabupaten Brebes.

Hal ini dapat ditunjukkan dari hasil analisis korelasi parsial diperoleh nilai $r$ sebesar 0,409. Pada taraf signifikansi $\mathrm{p}<$ 0,05, artinya hubungan variabel budaya kerja guru terhadap iklim organisasi sekolah termasuk pada kategori sedang dan signifikan. Selanjutnya dari hasil analisis regresi sederhana diperoleh nilai koefisien regresi ke arah positif sebesar 0,531 dengan konstanta 187,612 pada taraf signifikansi $p<0,05$.

Selain itu variabel komitmen guru memberi kontribusi sebesar $14,9 \%$ terhadap iklim organisasi sekolah. Kontribusi 14,9\% diperoleh dari Adjusted $R^{2}$, yaitu perolehan nilai yang telah disesuaikan dari adanya residu (kekeliruan tanggapan) responden. 
Model estimasi ini tergolong akurat dengan melihat output model summaryb dari Std. error of the estimate $<$ Std deviation Y $(11,588<12,561)$. Oleh karena itu dapat disimpulkan bahwa komitmen guru memberikan sumbangan yang signifikan terhadap iklim organisasi sekolah di Sekolah Dasar Kecamatan Ketanggungan Kabupaten Brebes.

Hasil ini sudah sesuai dengan teori yang dikehendaki, yaitu bahwa guru yang memiliki komitmen tinggi akan berusaha mengerahkan kemampuan dan perilakunya untuk memenuhi kebutuhan organisasi. Sehingga, semakin tinggi komitmen guru, semakin tinggi/baik pula iklim organisasi sekolah tersebut.

Pengaruh motivasi kerja guru terhadap iklim organisasi sekolah

Berdasarkan hasil uji hipotesis menunjukkan bahwa motivasi kerja guru berpengaruh signifikan terhadap iklim organisasi sekolah di Sekolah Dasar Kecamatan Ketanggungan Kabupaten Brebes. Hai ini dapat ditunjukkan dari hasil analisis korelasi parsial diperoleh nilai $r$ sebesar 0,318 . Pada taraf signifikansi $p<0,05$, artinya hubungan variabel motivasi kerja guru terhadap iklim organisasi sekolah termasuk pada kategori cukup kuat dan signifikan.

Selanjutnya dari hasil analisis regresi sederhana diperoleh nilai koefisien regresi ke arah positif sebesar 0,254 dengan konstanta 203,137 pada taraf signifikansi p < 0,05 . Selain itu variabel motivasi kerja guru memberi kontribusi sebesar 8,1\% terhadap iklim organisasi sekolah. Nilai 8,1\% diperoleh dari Adjusted $R^{2}$, yaitu perolehan nilai yang telah disesuaikan dari adanya residu (kekeliruan tanggapan) responden.

Model estimasi ini tergolong akurat dengan melihat output model summaryb dari Std. error of the estimate < Std deviation Y $(12,040<12,561)$. Oleh karena itu dapat disimpulkan bahwa motivasi kerja guru memberikan sumbangan yang signifikan terhadap iklim organisasi sekolah di Sekolah Dasar Kecamatan Ketanggungan Kabupaten Brebes.
Hal ini sudah sesuai dengan teori yang dikehendaki, yaitu bahwa motivasi kerja guru atau daya penggerak yang berarti suatu dorongan untuk mewujudkan perilaku tertentu yang terarah kepada pencapaian suatu tujuan tertentu. Guru dengan motivasi kerja tinggi akan senantiasa bekerja keras untuk mengatasi segala permasalahan yang dihadapi dengan harapan mencapai kinerja yang lebih baik.

Dengan demikian, sesuai dengan teori McClelland dengan tiga hal utamanya yaitu: dorongan untuk berprestasi, berafiliasi, penghargaan dan aktualisasi diri, bila ketiganya baik, maka iklim organisasi dapat tercipta dengan baik pula.

Pengaruh Budaya Kerja Guru, Komitmen Guru dan Motivasi Kerja Guru secara Bersama-sama terhadap Iklim Organisasi Sekolah

Berdasarkan hasil analisis regresi berganda diperoleh garis persamaan regresi $\hat{Y}=38,806+0,268 \mathrm{X} 1+0,378 \mathrm{X} 2+0,293 \mathrm{X} 3$. Hasil ini menunjukan tanda yang positif ini adalah sesuai dengan teori dan dapat dimaknai bahwa budaya kerja guru, komitmen guru dan motivasi kerja guru menunjukkan kategori baik maka iklim organisasi sekolah akan baik pula.

Hasil persamaan garis regresi tersebut dapat pula dimaknai sebagai berikut:

a. Konstanta bertanda positif ini menunjukkan jika ketiga variabel bebas tidak ada maka iklim organisasi sekolah sebesar 38,806.

b. Jika variabel budaya kerja guru meningkat satu poin maka iklim organisasi sekolah akan meningkat sebesar 0,268 dengan asumsi variabel komitmen guru dan motivasi kerja guru konstan.

c. Jika variabel komitmen guru meningkat satu poin maka iklim organisasi sekolah akan meningkat sebesar 0.378 dengan asumsi variabel motivasi kerja guru dan budaya kerja guru konstan.

d. Jika variabel motivasi kerja guru meningkat satu poin maka variabel iklim organisasi sekolah akan meningkat se- 
besar 0,293 dengan asumsi variabel budaya kerja guru dan komitmen guru konstan.

Pengaruh budaya kerja guru sebesar $18,1 \%$, pengaruh ini lebih besar, hal ini dikarenakan guru yang memiliki budaya kerja tinggi dalam menjalankan tugas profesionalnya dapat mengubah sikap dan perilakunya melalui pola pikir, tingkah laku, dan tatanan kerja serta mampu beradaptasi terhadap perubahan, menuju terciptanya iklim organisasi sekolah yang baik.

Hasil ini sudah sesuai dengan teori yang dikehendaki, yaitu bahwa guru yang memiliki budaya kerja yang baik dalam tugasnya, dapat memberikan pengaruh yang kuat terhadap kondisi lingkungan sekitarnya, sehingga dapat tercipta iklim organisasi yang sehat.

Guru yang memiliki budaya kerja tinggi senantiasa bekerja keras untuk mengatasi segala permasalahan yang dihadapi dengan harapan mencapai kinerja yang lebih baik. Guru yang melaksanakan tugas dengan penuh tanggung jawab, menjunjung nilai kejujuran, tekun dan memiliki kreativitas serta dapat mengembangkan keahliannya dapat mewujudkan iklim sekolah yang sehat, kondusif, dan humanis. Kondisi iklim sekolah yang kondusif, sehat dan humanis dapat berujung pada meningkatnya mutu pendidikan secara keseluruhan.

Selanjutnya pengaruh komitmen guru sebesar $14,9 \%$ ditunjukkan dengan adanya tujuan pribadi guru yang rela menyumbangkan sesuatu bagi tercapainya tujuan organisasi, keterlibatan guru dalam berpartisipasi melaksanakan sesuatu yang telah diputuskan bersama, loyalitas dan kesediaan pegawai untuk mempertahankan diri bekerja dalam organisasi. Hal ini dapat diupayakan bila pegawai merasakan adanya keamanan dan kepuasan di dalam organisasi tempat ia bergabung untuk bekerja.

Pengaruh motivasi kerja guru terhadap iklim organisasi sekolah menunjukan hasil koefisien regresi yang positif dan signifikan, berarti bahwa semakin tinggi motivasi kerja guru untuk melakukan pekerjaan sebagai guru maka iklim organisasi sekolah akan meningkat. Guru dengan motivasi kerja tinggi akan senantiasa bekerja keras untuk mengatasi segala permasalahan yang dihadapi dengan harapan mencapai kinerja yang lebih baik.

Mencermati iklim organisasi sekolah sebagai sebuah sistem maka iklim organisasi sekolah tidak lepas dari tingkah laku pegawai. Hal ini sesuai dengan pendapat Higgins (Hardjana, 2006: 22-23), tingkah laku pegawai mempengaruhi iklim melalui kepribadian mereka, terutama kebutuhan mereka dan tindakan yang mereka lakukan. Dan komunikasi pegawai memainkan bagian penting dalam membentuk iklim.

Komunikasi yang baik dapat menentukan tingkat suksesnya hubungan antar manusia, sehingga dapat menciptakan iklim yang positif. Selanjutnya, sesuai juga pendapat Forehand (Hardjana, 2006, p.6) yang menyatakan iklim organisasi sekolah dipengaruhi oleh tujuan organisasi dan jaringan komunikasi. Artinya, jika tujuan organisasi dan jaringan komunikasi membaik, maka iklim organisasi sekolah akan meningkat menjadi baik pula.

Kenyataan sebenarnya yang mempengaruhi iklim organisasi sekolah tidak hanya budaya kerja guru, komitmen guru dan motivasi kerja guru, masih banyak faktor lain dan sangat kompleks oleh karenanya faktor lain di luar model penelitian ini yang mempengaruhi iklim organisasi sekolah di SD sebesar $58.2 \%$. Faktor di luar model regresi penelitian ini misalnya produktivitas, supervisi oleh kepala sekolah, kepuasan kerja, kompetensi pedagogik dan lain sebagainya yang tidak diteliti.

\section{Simpulan dan Saran}

\section{Simpulan}

Berdasarkan hasil penelitian, analisis data dan pembahasan tentang pengaruh budaya kerja guru, komitmen guru, dan motivasi kerja guru terhadap iklim organisasi sekolah, maka dapat ditarik kesimpulan sebagai berikut 
Pertama, ada pengaruh positif dan signifikan budaya kerja guru terhadap iklim organisasi sekolah. Pengaruh positif itu bahwa jika budaya kerja guru semakin baik maka iklim organisasi sekolah semakin baik

Kedua, ada pengaruh positif dan signifikan komitmen guru terhadap iklim organisasi sekolah. Pengaruh positif itu bahwa jika komitmen guru semakin baik maka iklim organisasi sekolah semakin baik.

Ketiga, ada pengaruh positif dan signifikan motivasi kerja guru terhadap iklim organisasi sekolah, pengaruh positif itu bahwa jika motivasi kerja guru semakin baik maka iklim organisasi sekolah semakin baik.

Keempat, ada pengaruh positif dan signifikan budaya kerja guru, komitmen guru dan motivasi kerja guru terhadap iklim organisasi sekolah. Pengaruh positif itu bahwa jika budaya kerja guru, komitmen guru dan motivasi kerja guru semakin baik maka iklim organisasi sekolah semakin baik.

Saran

Saran-saran yang dapat disampaikan berdasarkan simpulan dan implikasi di atas sebagai berikut.Pertama, Kepala UPTD Pendidikan diharapkan dapat memberikan pelatihan, pembinaan dan pengawasan serta penataan yang optimal melalui pengawas daerah binaan masing-masing, berkaitan dengan peningkatan budaya kerja guru, komitmen guru dan motivasi kerja guru, agar dapat tercipta iklim organisasi sekolah yang sehat.

Kedua, pengelolaan iklim organisasi bagi sekolah perlu disempurnakan melalui peningkatan budaya kerja, komitmen dan motivasi kerja guru, agar tercipta kerja sama tim yang prima serta hubungan kerja berdasarkan pendekatan partisipasi, demi terwujudnya iklim sekolah yang sehat.

Ketiga, diharapkan kepada guru-guru di Kecamatan Ketanggungan untuk terus meningkatkan budaya kerja, komitmen dan motivasi kerjanya, karena semakin baik budaya kerja, komitmen dan motivasi kerja guru maka akan semakin baik pula iklim organisasi sekolah. Untuk peningkatan tersebut setiap ada pelatihan dan pembinaan yang bertujuan untuk memberikan wawasan pendidikan, guru seharusnya ikut serta, agar dapat meningkatkan budaya kerja, komitmen dan motivasi kerjanya, sehingga iklim organisasi yang kondusif dapat tercapai.

Keempat, Penelitian ini belum komprehensif, karena hanya melihat iklim organisasi dari pengaruh budaya kerja, komitmen dan motivasi kerja guru, maka untuk kebutuhan penelitian berikutnya bagi yang berminat meneliti iklim organisasi dapat melihat dari faktor yang lain, yaitu tingkat kepatuhan guru dari kebijakan UPTD, hubungan kerja berdasarkan pendekatan partisipasi, dan tanggapan guru dari kontrol masyarakat terhadap sekolah.

\section{Daftar Pustaka}

Angle, H., \& Perry, J. L. (1981). An empirical assessment of organizational commitment and organizational effectiveness. Administrative Science Quarterly, Vol. 26 No.1, pp.1-14.

Davis, K., \& Newstrom, J. W. (1985). Perilaku dalam organisasi. Terjemahan Agus Dharma. Jakarta: Erlangga.

Greenberg, J., \& Baron, R. A. (2003). Behavior in organizations: Understanding and managing the human side of work. $\left(8^{\text {th }}\right.$ ed). New Jersey: Prentice-Hall, Inc.

Hersey, P., \& Blancard, K. (1982). Management of organizational behavior: Utilizing human resources. ( $4^{\text {th }} \mathrm{ed}$ ). New Jersey: Prentice-Hall, Inc.

Kausal, S. L., (2010). A Survey on work culture and ethnical behavior: A case study of HP police force. Productivity 50.4 (Jan-Mar 2010): 319-325

Lunenburg, F.C., \& Ornstein, A. (1999). Educational administration: Concepts and practices $\left(3^{\text {th }} \mathrm{ed}\right)$. p. $\mathrm{cm}$. United States. 
Organisasi.Org. komunitas \& perpustakaan online Indonesia. (2007). Arti definisi/pengertian budaya kerja dan tujuan/manfaat penerapan budaya kerja. http://organisasi.org/arti-definisipengertian-budaya-kerja-dantujuan. diambil 12 Juni 2013.

Robbins, S. P. (2006). Perilaku organisasi: Konsep kontroversi, aplikasi. ed Indonesia. Jakarta: PT. Prenhallindo.

Sudarmanto. (2009). Kinerja dan pengembangan kompetensi SDM: Teori, dimensi pengukuran, dan implementasi dalam organisasi. Yogyakarta: Pustaka Pelajar.
Sugiyono. (2011). Metode penelitian pendidikan. Bandung: Alfabeta

Steers, R. M. (1985). Efektivitas organisasi. terjemahan Magdalena Jamin. Jakarta: Erlangga.

Usman, H. (2013). Manajemen: Teori, praktik, dan riset pendidikan. Jakarta: Bumi Aksara.

Wirawan. (2008). Budaya dan iklim organisasi: Teori aplikasi dan penelitian. Jakarta: Salemba Empat.

Wuradji. (2009). The educational leadership. Yogyakarta: Gama Media. 